\title{
LIETUVOS MOKSLEIVIŲ PASITENKINIMAS GYVENIMU: HBSC TYRIMO REZULTATAI
}

\author{
Justė Lukoševičiūtė, Kastytis Šmigelskas \\ Lietuvos sveikatos mokslu universitetas
}

Raktažodžiai: pasitenkinimas gyvenimu, subjektyvus sveikatos įvertinimas, gerove, moksleiviai, HBSC tyrimas.

\begin{abstract}
Santrauka
Gera fizinè ir psichologinè savijauta bei palanki socialinė aplinka leidžia jauniems žmonėms nesunkiai ivveikti paauglystejje kylančius sunkumus ir sumažina riziką rimtesnèms sveikatos problemoms ateityje. Šiuo tyrimu buvo siekiama nustatyti subjektyvaus sveikatos ịvertinimo ir psichologinès gerovès rodikliụ svarbą pasitenkinimui gyvenimu. Duomenys rinkti vadovaujantis tarptautiniu HBSC tyrimo protokolu, 2018 m. surinkta reprezentatyvi Lietuvos moksleivių imtis: apklaustas 4191 mokinys iš 5, 7 ir 9 klasių (berniukų 50,9 proc., mergaičių 49,1 proc., amžiaus

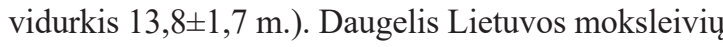
yra patenkinti savo gyvenimu (87 proc.). Prastesnis pasitenkinimas gyvenimu būdingas mergaitėms, vyresniems moksleiviams iš žemesnès socialinès-ekonominès padèties šeimų. Vertinant pasitenkinimą gyvenimu didžiausios svarbos turèjo bendra psichologinė gerovè ir subjektyvus sveikatos vertinimas.
\end{abstract}

\section{Ivadas}

Pasitenkinimas gyvenimu (angl. life satisfaction) - vienas svarbiausių rodiklių, atspindinčių asmens gyvenimo kokybę [1]. Tyrimai rodo, kad tai yra gana stabilus rodiklis, kitaip nei emocijos ar jausmai, kurie gali būti tiesiogiai susiję su tuometine patirtimi ar išgyvenimais. Pasitenkinimas gyvenimu gali būti veikiamas ịvairių gyvenimo patirčių, santykių ar socialinès aplinkos [2]. Tai gana lengvai suprantamas, ivvertinamas ir interpretuojamas rodiklis jau mokyklinio amžiaus vaikams.

HBSC (angl. Health Behaviour in School-aged Children) tyrimas yra ilgametis vaikų ir paauglių iki $18 \mathrm{~m}$. gyvensenos bei sveikatos tyrimas, kuriame be kitų rodiklių taip pat yra vertinamas ir pasitenkinimas gyvenimu. Lietuvoje atliekant HBSC tyrimus, šis rodiklis yra stebimas nuo 2002 metų ir jo dinamika rodo, kad vaikų ir paauglių pasitenkinimas gyve- nimu palaipsniui gerejja: jei $2002 \mathrm{~m}$. patenkintų gyvenimu buvo 75 proc., tai $2018 \mathrm{~m}$. - jau 87 proc. (1 pav.).

Per du dešimtmečius publikuoti medicininiai moksliniai straipsniai atskleidè, kad sveikatos priežiūros srityje vertinant asmens sveikatą vis dažniau vadovaujamasi biopsichosocialiniu požiūriu [3]. Kalbant apie fizinę savijautą, vienas iš rodiklių, atskleidžiančių asmens sveikatos būklę, yra subjektyvus savo sveikatos įvertinimas (angl. self-rated health). Jauname amžiuje šis rodiklis atspindi ne tik ligų (ne)buvimą, tačiau taip pat ir bendrą savęs supratimą [2]. Tyrimai rodo, kad savo sveikatos įvertinimas nèra vien subjektyvus matmuo - prastas savo sveikatos ịvertinimas jauname amžiuje siejamas su sveikatos problemomis suaugus [4] ir stipriai koreliuoja bei prognozuoja su sveikata susijusias baigtis [5]. Ilgalaikiai empiriniai tyrimai atskleidžia, kad subjektyvus savo sveikatos ịvertinimas yra vienas iš nepriklausomu veiksnių, prognozuojančių mirtingumą, nepriklausomai nuo kitų tradicinių rizikos veiksnių [6].

Vertinant socialinius ir psichologinius asmens sveikatos komponentus kol kas vis dar trūksta išsamių rodiklių. Pasaulio sveikatos organizacija (PSO) skatina nepamiršti psichikos sveikatos ir greta fizinių sveikatos nusiskundimu skirti dèmesi psichologinei asmens savijautai, kuri dažnai yra įvardijama kaip gerovè (angl. well-being). Atsižvelgdami ị tai, psichikos sveikatos PSO ekspertai $1998 \mathrm{~m}$. sudare bendrą gerovès indeksą, kuriuo įvertinami geriausiai emocinę būklę atspindintys aspektai, tokie kaip linksmumas, atsipa-

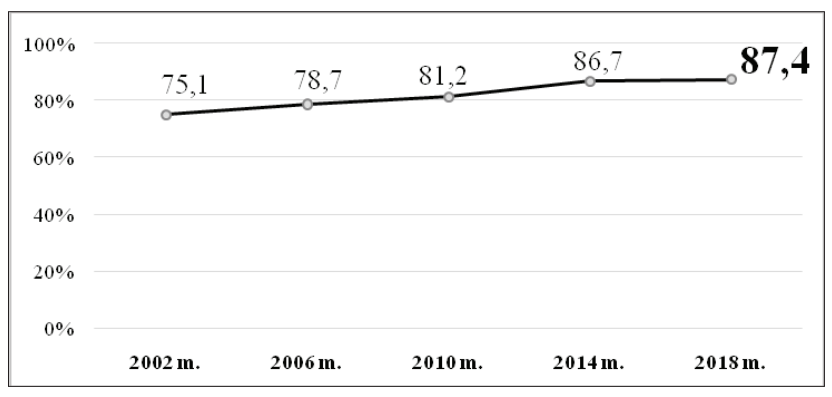

1 pav. Pasitenkinimo gyvenimu dinamika tarp Lietuvos moksleivių. 
laidavimas, energingumas, žvalumas ar domèjimasis kasdieniais dalykais [7].

Daugiau nei prieš dešimtmetị publikuoti tyrimai rodo, kad pasitenkinimas gyvenimu yra glaudžiai susijęs tiek su subjektyviu savo sveikatos vertinimu, tiek su bendra asmens gerove [1]. Mūsų tyrimu norèta įvertinti, ar tokios sąsajos yra ir šiuo metu, pasikeitus socialinems kartoms.

Analizès tikslas - nustatyti subjektyvaus sveikatos vertinimo ir psichologinès gerovès rodiklių svarbą pasitenkinimui gyvenimu tarp Lietuvos moksleivių.

\section{Tyrimo metodai}

Tyrimo eiga ir imtis. HBSC - vienintelis paaugliu gyvensenos ir sveikatos stebèsenos tyrimas Europoje, atliekamas pagal vieningą tarptautinị tyrimo protokolą. Tyrimas vykdomas kas ketverius metus PSO iniciatyva ir apima 50 Europos, Šiaurès Amerikos ir Azijos šalių. Lietuvoje šis tyrimas pradètas vykdyti 1994 metais ir tęsiamas iki šiol. $2018 \mathrm{~m}$. buvo atliktas 7-asis tokio tipo tyrimas, leidžiantis įvertinti 25 metų tendencijas.

Lietuvos sveikatos mokslų universiteto (LSMU) Visuomenès sveikatos fakulteto Sveikatos tyrimų institutas, bendradarbiaudamas su PSO ir Lietuvos Respublikos švietimo ir mokslo ministerija (LR ŠMM), 2018 m. balandžiobirželio mènesiais atliko tarptautinị HBSC tyrimą visoje Lietuvoje. Tyrimui atlikti buvo gauti LR ŠMM (2018-04-27 Nr. SR-1843), LSMU Bioetikos centro (2018-03-08 Nr. BEC-89) ir savivaldybių švietimo skyrių, mokyklų vadovų bei tèvų pritarimai.

Tyrimo duomenys buvo rinkti vadovaujantis tarptautiniu HBSC tyrimo protokolu, tiriamieji atrinkti laikantis reprezentatyvios imties sudarymo principų, atsitiktinai atrenkant mokyklas (apklaustos 64 Lietuvos bendrojo ugdymo mokyklos). Apklausas vykde nepriklausomi ir specialiai HBSC tyrimui apmokyti tyrèjai. Iš viso buvo apklaustas 4191 mokinys iš 5, 7 ir 9 klasių (berniukų

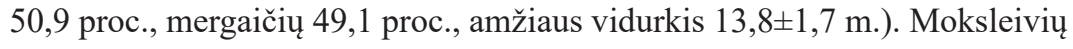
atsako dažnis sieké 80,5 proc.

1 lentelẻ. Tyrimo reiškinių pasiskirstymas pagal demografinius ir socialinius-ekonominius rodiklius.

\begin{tabular}{|c|c|c|c|c|c|c|}
\hline \multirow[b]{2}{*}{ Veiksnys } & \multicolumn{2}{|c|}{ Sveikatos vertinimas } & \multicolumn{2}{|c|}{ Psichologinè gerovè } & \multicolumn{2}{|c|}{ Pasitenkinimas gyvenimu } \\
\hline & $\begin{array}{c}\text { Puiki } \\
\text { arba gera }\end{array}$ & $\begin{array}{c}\text { Patenkinama } \\
\text { arba bloga }\end{array}$ & $\begin{array}{c}\text { Aukštesnè } \\
\text { nei vidutinè }\end{array}$ & $\begin{array}{c}\text { Žemesnè } \\
\text { nei vidutiné }\end{array}$ & $\begin{array}{c}\text { Aukštesnis } \\
\text { nei vidutinis }\end{array}$ & $\begin{array}{c}\text { Žemesnis } \\
\text { nei vidutinis }\end{array}$ \\
\hline \multicolumn{7}{|l|}{ Lytis, proc. } \\
\hline Berniukai & 89,8 & 10,2 & 75,0 & 25,0 & 90,0 & 10,0 \\
\hline Mergaitès & 84,7 & 15,3 & 62,4 & 37,6 & 84,8 & 15,2 \\
\hline$\chi^{2}$ & \multicolumn{2}{|c|}{24,90} & \multicolumn{2}{|c|}{75,87} & \multicolumn{2}{|c|}{25,03} \\
\hline $\mathrm{p}$ & \multicolumn{2}{|c|}{$<0,001$} & \multicolumn{2}{|c|}{$<0,001$} & \multicolumn{2}{|c|}{$<0,001$} \\
\hline \multicolumn{7}{|l|}{ Klasė, proc. } \\
\hline 5 klasè & 93,3 & 6,7 & 78,8 & 21,2 & 93,6 & 6,4 \\
\hline 7 klasè & 87,0 & 13,0 & 66,0 & 34,0 & 85,7 & 14,3 \\
\hline 9 klasė & 81,8 & 18,2 & 61,5 & 38,5 & 83,2 & 16,8 \\
\hline$\chi^{2}$ & \multicolumn{2}{|c|}{84,22} & \multicolumn{2}{|c|}{103,21} & \multicolumn{2}{|c|}{73,42} \\
\hline $\mathrm{p}$ & \multicolumn{2}{|c|}{$<0,001$} & \multicolumn{2}{|c|}{$<0,001$} & \multicolumn{2}{|c|}{$<0,001$} \\
\hline \multicolumn{7}{|c|}{ Šeimos socialinè-ekonominė padėtis, proc. } \\
\hline Žemiausia & 84,6 & 15,4 & 63,1 & 36,9 & 82,2 & 17,8 \\
\hline Vidutinè & 87,6 & 12,4 & 69,2 & 30,8 & 87,6 & 12,4 \\
\hline Aukščiausia & 90,3 & 9,7 & 74,0 & 26,0 & 93,2 & 6,8 \\
\hline$\chi^{2}$ & \multicolumn{2}{|c|}{10,55} & \multicolumn{2}{|c|}{19,81} & \multicolumn{2}{|c|}{38,62} \\
\hline $\mathrm{p}$ & \multicolumn{2}{|c|}{0,005} & \multicolumn{2}{|c|}{$<0,001$} & \multicolumn{2}{|c|}{$<0,001$} \\
\hline Iš viso & 87,3 & 12,7 & 68,7 & 31,3 & 87,5 & 12,5 \\
\hline
\end{tabular}

Tyrimo instrumentai. Tyrime naudotos anoniminès anketos, sudarytos atliekant dvigubą vertimą iš anglų kalbos.

Subjektyvi moksleivių sveikata buvo vertinta užduodant tiesioginį klausimą: „Kaip apibūdintum savo sveikatą?“, atsakymus nurodant nuo „puiki“ iki „bloga“ [8].

Pasitenkinimas gyvenimu vertintas pasitelkiant Cantril kopéčių vizualizaciją [9], kur kopéčių viršus interpretuojamas, kad moksleivis yra „labiausiai patenkintas (-a) savo gyvenimu“, o apačia - ,,mažiausiai patenkintas (-a) gyvenimu“".

Psichologinè gerovè vertinta naudojant PSO sukurtą Psichologinès gerovès indeksą (angl. WHO-Five Well-being Index; WHO-5). Indeksu nagrinejami emocinę būklę atspindintys aspektai, vertinant juos Likerto skaleje [7]. Vidinis skalès suderintumas šiame tyrime buvo geras (Cronbach $\alpha=0,84$ ).

I šią analizę taip pat buvo įtraukti klausimai apie moksleivių lytị, klasę ir šeimos socialinę-ekonominę padètị (SEP), kuri vertinta pagal Šeimos turtingumo skalę (angl. Family Affluence Scale-III), vèliau kategorizuojant $i$ tris grupes pagal tarptautines rekomendacijas [2].

Duomenų analizė. Tyrimo duomenys suvesti ir koduoti „MS Excel“" programoje, o statistinè duomenų analizè atlikta naudojant „IBM SPSS 20.0“ programą. Rezultatai laikyti statistiškai reikšmingais, kai $\mathrm{p}<0,05$.

Kintamujų dichotomizacija atlikta laikantis HBSC tyrime rekomenduojamų ribinių reikšmių [2]. Siekiant subalansuoti tyrimo grupes pagal lytị ir klasę, skaičiavimuose buvo taikyti svertiniai koeficientai.

Analitineje statistikoje atliekant dvimatę analizę reiškinių pasiskirstymui tarp grupių palyginti buvo taikytas chi kvadratu $\left(\chi^{2}\right)$ kriterijus, ranginių kintamujų ryšiams įvertinti - Spirmeno koreliacijos koeficientas (@). Tyrime buvo taikyta vienaveiksnè ir daugiaveiksnè logistinè regresinè analizè, apskaičiuojant galimybių santykius (GS) ir jų 95 proc. pasikliautinuosius intervalus (PI). Referencine grupe 
( $\mathrm{GS}=1,00)$ buvo laikoma ta moksleivių grupe, kuriai buvo būdingas didesnis problemos išreikštumas, o apskaičiuotosios reikšmès nurodo gero pasitenkinimo gyvenimu statistinius šansus.

\section{Rezultatai}

Lietuvos moksleiviu sveikatos ir gerovės ypatumai. Pagrindiniai šiame tyrime nagrinèti reiškiniai - subjektyvus moksleivių savo sveikatos vertinimas, pasitenkinimas gyvenimu ir psichologine gerovè. Išsamus šių dichotominių veiksnių pasiskirstymas pagal tiriamujų demografines ir šeimos socialines-ekonomines charakteristikas pateiktas 1 lenteleje.

Tyrimas atskleide, kad beveik 87 proc. moksleivių savo sveikatą vertino kaip puikią arba gerą. Ivertinus tyrime dalyvavusių moksleivių psichologinę gerovę nustatyta, kad beveik trečdaliui moksleivių (31 proc.) būdinga žemesnè nei vidutinè psichologinè gerovè. Aukštesnis nei vidutinis pasitenkinimas gyvenimu bendrai tyrimo imtyje buvo nustatytas 87 proc. vaikų ir paauglių. Vertinant šiuos tris reiškinius pagal demografines ir socialines-ekonomines moksleivių charakteristikas nustatytos sistemingos sąsajos: reikšmingai prastesniais rodikliais pasižymėjo mergaitès, vyresniujų klasių moksleiviai ir žemiausiai grupei pagal šeimos socialinę-ekonominę padètį priskirti moksleiviai $(\mathrm{p}<0,05)$. Bendrai vertinant šiuos rodiklius pagal lytį, klasę ir šeimos turtingumą galima pastebèti, kad palankiausiai savo sveikatą ir gerovę vertino 5 klasių moksleiviai.

Sveikatos vertinimo ir psichologinès gerovès svarba pasitenkinimui gyvenimu. Siekiant ịvertinti subjektyvios sveikatos ir psichologinès gerovės svarbą moksleivių pasitenkinimui gyvenimu, tyrime buvo taikyta logistinè regresinè analizè (2 lentelè).

Vienaveiksnès regresinès analizès rezultatai atskleide, kad visi tyrime nagrinèti veiksniai yra statistiškai reikšmingai susiję su moksleivių pasitenkinimu gyvenimu $(\mathrm{p}<0,001)$. Labiausiai išsi-
2 lentelè. Subjektyvaus sveikatos vertinimo ir psichologinès gerovės svarba pasitenkinimui gyvenimu: vienaveiksnè ir daugiaveiksnè logistinè regresinė analizè.

Pastaba: GS-galimybiu santykis; PI-pasikliautinasis intervalas.

\begin{tabular}{|c|c|c|c|c|c|c|c|}
\hline \multirow{2}{*}{\multicolumn{2}{|c|}{ Veiksnys }} & \multicolumn{3}{|c|}{ Vienaveiksnė } & \multicolumn{3}{|c|}{ Daugiaveiksnè } \\
\hline & & \multirow{2}{*}{$\begin{array}{l}\text { GS } \\
9,58 \\
\end{array}$} & \multirow{2}{*}{\begin{tabular}{|l|}
$\mathbf{9 5} \%$ PI \\
$7,75-11,83$ \\
\end{tabular}} & \multirow{2}{*}{\begin{tabular}{l|l}
$\mathbf{p}$ \\
$<0,001$
\end{tabular}} & \multirow{2}{*}{\begin{tabular}{|l|} 
GS \\
5,67
\end{tabular}} & \multirow{2}{*}{$\begin{array}{l}\mathbf{9 5} \% \text { PI } \\
4,48-7,17 \\
\end{array}$} & \multirow{2}{*}{\begin{tabular}{|l|}
$\mathbf{p}$ \\
$<0,001$ \\
\end{tabular}} \\
\hline Sveikatos vertinimas & Gera & & & & & & \\
\hline sverkatos vertintmias & Prasta & 1,00 & - & - & 1,00 & - & - \\
\hline \multirow{2}{*}{$\begin{array}{l}\text { Linksmumas ir gera } \\
\text { nuotaika }\end{array}$} & Išreikšta & 9,88 & $8,08-12,08$ & $<0,001$ & & & \\
\hline & Neišreikšta & 1,00 & - & - & & & \\
\hline \multirow{2}{*}{$\begin{array}{l}\text { Ramumas ir atsipalai- } \\
\text { davimas }\end{array}$} & Išreikšta & 5,62 & $4,58-6,89$ & $<0,001$ & & & \\
\hline & Neišreikšta & 1,00 & - & - & & & \\
\hline \multirow{2}{*}{$\begin{array}{l}\text { Aktyvumas ir ener- } \\
\text { gingumas }\end{array}$} & Išreikšta & 4,82 & $3,97-5,85$ & $<0,001$ & & & \\
\hline & Neišreikšta & 1,00 & - & - & & & \\
\hline \multirow{2}{*}{$\begin{array}{l}\text { Žvalumas ir pailsèji- } \\
\text { mas atsibudus }\end{array}$} & Išreikšta & 4,31 & $3,43-5,42$ & $<0,001$ & & & \\
\hline & Neišreikšta & 1,00 & - & - & & & \\
\hline \multirow{2}{*}{$\begin{array}{l}\text { Domėjimasis kasdie- } \\
\text { niais dalykais }\end{array}$} & Išreikšta & 5,75 & $4,69-7,06$ & $<0,001$ & & & \\
\hline & Neišreikšta & 1,00 & - & - & & & \\
\hline \multirow{2}{*}{ Psichologinè gerovè } & Aukšta & 9,17 & 7,39-11,37 & $<0,001$ & 6,11 & $4,85-7,69$ & $<0,001$ \\
\hline & Žema & 1,00 & - & - & 1,00 & - & - \\
\hline \multirow{2}{*}{ Lytis } & Berniukai & 1,61 & $1,33-1,94$ & $<0,001$ & 1,09 & $0,88-1,36$ & 0,427 \\
\hline & Mergaitès & 1,00 & - & - & 1,00 & - & - \\
\hline \multirow{3}{*}{ Klasė } & 5 klasė & 2,96 & $2,29-3,83$ & $<0,001$ & 1,71 & $1,27-2,30$ & $<0,001$ \\
\hline & 7 klasė & 2,44 & $1,87-3,18$ & $<0,001$ & 1,71 & $1,28-2,30$ & $<0,001$ \\
\hline & 9 klasė & 1,00 & - & - & 1,00 & - & - \\
\hline \multirow{3}{*}{$\begin{array}{l}\text { Šeimos socialinè- } \\
\text { ekonominè padètis }\end{array}$} & Aukščiausia & 2,97 & $2,08-4,25$ & $<0,001$ & 2,41 & $1,61-3,59$ & $<0,001$ \\
\hline & Vidutinè & 1,94 & $1,40-2,68$ & $<0,001$ & 1,73 & $1,21-2,47$ & 0,003 \\
\hline & Žemiausia & 1,00 & - & - & 1,00 & - & - \\
\hline
\end{tabular}

3 lentelè. Psichologinės gerovès skalès teiginių tarpusavio koreliacijos (@). Pastaba: visos koreliacijos $p<0,001$.

\begin{tabular}{|l|c|c|c|c|c|}
\hline Teiginys & $\mathbf{1 .}$ & $\mathbf{2 .}$ & $\mathbf{3 .}$ & $\mathbf{4 .}$ & $\mathbf{5 .}$ \\
\hline 1. Linksmumas ir gera nuotaika & - & 0,61 & 0,55 & 0,49 & 0,53 \\
\hline 2. Ramumas ir atsipalaidavimas & 0,61 & - & 0,49 & 0,50 & 0,48 \\
\hline 3. Aktyvumas ir energingumas & 0,55 & 0,49 & - & 0,49 & 0,51 \\
\hline 4. Žvalumas ir pailsèjimas atsibudus & 0,49 & 0,50 & 0,49 & - & 0,50 \\
\hline 5. Domėjimasis kasdieniais dalykais & 0,53 & 0,48 & 0,51 & 0,50 & - \\
\hline
\end{tabular}

skyrè emocinè savijauta - tyrime paaiškejjo, kad linksmumas ir gera nuotaika (GS=9,88; $p<0,001)$, subjektyvus savo sveikatos vertinimas $(G S=9,58 ; p<0,001)$ bei bendra psichologinè gerovè $(G S=9,17 ; p<0,001)$ yra teigiamai susiję su pasitenkinimu gyvenimu.

Kadangi psichologinès gerovės klausimai sudaro bendrą skalę, siekiant išvengti multikolinearumo problemos daugiaveiksniame modelyje, buvo ịvertintos šių klausimų tarpusavio sąsajos. Koreliacinè analizè atskleidè (3 lentelè), kad nagrinėjamų psichologinès gerovės aspektų koreliacijos varijavo nuo 0,48 iki 0,61. Atkreiptinas dèmesys, kad visos šių teiginių tarpusavio koreliacijos buvo statistiškai reikšmingos $\mathrm{p}<0,001$ lygmenyje. Dẻl to, atsižvelgiant ị tokias sąsajas, daugiaveiksniame logistinès regresinès analizės modelyje buvo įtrauktas tik bendrasis psichologinès gerovès kintamasis.

Daugiaveiksnès regresijos analizè parodè, kad stipriausi nepriklausomi prognostiniai veiksniai, susiję su pasitenkinimu gyvenimu, buvo psichologinè gerovè $(G S=6,11 ; p<0,001)$ ir sveikatos vertinimas $(G S=5,67 ; p<0,001)$. Geresni pasitenkinimą gyvenimu taip pat reikšmingai prognozavo jaunesnis amžius 
(penktokų ir septintokų GS=1,71; $\mathrm{p}<0,001$ ) ir geresne šeimos socialinè-ekonominè padètis (vidutinio turtingumo $\mathrm{GS}=1,73$; $\mathrm{p}=0,003$, aukšto turtingumo $\mathrm{GS}=2,41 ; \mathrm{p}<0,001)$. Iš visų $i$ daugiaveiksni modeli įtrauktų veiksnių tik lytis neturèjo statistiškai reikšmingos svarbos prognozuojant moksleivių pasitenkinimą gyvenimu.

\section{Aptarimas}

Paauglystejje jauni žmonès susiduria su ịvairiais iššūkiais - fiziologiniais ir emociniais, su lytine branda susijusiais pokyčiais, besikeičiančiais santykiais su tèvais ir bendraamžiais, didëjančiais lūkesčiais akademinių pasiekimų atžvilgiu, rizikingos elgsenos pavojais ir kt. Gera fizinè ir psichologine savijauta bei palanki socialinè aplinka sudaro sąlygas jauniems žmonėms lengviau įveikti šiuos sunkumus. Tyrimai rodo, kad jau paauglysteje susiformuoja gyvensenos ịpročiai, požiūris ị savo sveikatą, o emocinè savijauta gali atsiliepti ir bendrai gyvenimo kokybei [10].

Atsižvelgiant ị tai, mūsų tyrime buvo įtraukti fizinę ir psichologinę savijautą bei socialinius moksleivių ypatumus atskleidžiantys rodikliai bei analizuota šių veiksnių svarba moksleivių pasitenkinimui gyvenimu. Mūsų tyrimas atskleidè, kad Lietuvoje 87 proc. moksleivių jaučiasi patenkinti savo gyvenimu. Žemesniu pasitenkinimu gyvenimu pasižymèjo mergaitès, vyresniujjų klasių moksleiviai ir žemiausiai grupei pagal šeimos socialinę-ekonominę padèti priskirti moksleiviai. Didžiausios svarbos vertinant pasitenkinimą gyvenimu turejo bendra psichologinė gerovė ir subjektyvus savo sveikatos vertinimas.

Tarptautinè $2014 \mathrm{~m}$. HBSC tyrimo ataskaita [2] parodè, kad vertinant Lietuvos moksleivių pasitenkinimą gyvenimu tarp kitų HBSC tyrime dalyvavusių šalių, mūsų šalies vaikų ir paauglių pasitenkinimas gyvenimu buvo šiek tiek geresnis nei bendras visų šalių vidurkis. Šioje ataskaitoje atsispindi šalių tendencijos: pasitenkinimas gyvenimu mažèja vyresniame moksleivių amžiuje, o aukštesnis pasitenkinimas gyvenimu nustatytas tarp berniukų ir labiau pasiturinčiose šeimose, ką patvirtino ir mūsų $2018 \mathrm{~m}$. tyrimo duomenys.

Aptariant socialinius-ekonominius ypatumus, tyrimai suaugusiujų imtyse atskleidžia analogiškas sąsajas - asmenys, priklausantys žemesnei ekonominei klasei, yra mažiau patenkinti gyvenimu lyginant su kitais, ir tai atsispindi įvairiose amžiaus grupėse [11]. Galima kelti hipotezę, kad ekonominiai netolygumai sudaro sąlygas vieniems būti pranašesniems už kitus, o negalejimas aprūpinti šeimos finansiškai tikriausiai užkerta sąlygas visaverčiam gyvenimui. Vertinant pasitenkinimo gyvenimu sąsajas tarp lyčių, tyrimų duomenys nèra tokie sistemingi: vieni tyrimai rodo, kad moterys jaučia didesnį pasitenkinimą gyvenimu [12], kiti sistemingų sąsajų neaptinka [13]. Šie neaiškumai rodo panašaus pobūdžio tyrimų poreiki ateityje.
Tai, kad pasitenkinimas gyvenimu glaudžiai siejasi su bendra psichologine gerove, rodo ir užsienio tyrejjų darbai. Tokios sąsajos dažnai aiškinamos tuo, kad pasitenkinimas gyvenimu yra laikomas kognityviuoju gerovès komponentu [14]. Sistemingus pasitenkinimo gyvenimu ryšius su sveikatos įvertinimu patvirtina ir kohortinių tyrimų rezultatai, kur geresnis savo sveikatos įvertinimas ir didesnis pasitenkinimas gyvenimu susiję su sėkmingesniu senejjimu (angl. successful aging) [15]. Turint omenyje, kad Lietuvos visuomenė senėja, šie rezultatai ypač svarbūs galvojant apie ateitị ir siekiant sumažinti sveikatos priežiūros išlaidas ateityje.

Tyrimų, nagrinejjusių paauglių pasitenkinimo gyvenimu sąsajas su savo sveikatos ịvertinimu ir psichologine gerove, kol kas nèra daug - didžioji dauguma mokslinių tyrimų atliekama vertinant vyresnių ir senyvo amžiaus žmonių imtis. Pavyzdžiui, Lietuvoje atliktas tyrimas parodè, kad savo sveikatos ịvertinimas teigiamai susijęs su subjektyviu paauglių burnos higienos įsivertinimu [16], nors bendrasis savo sveikatos įvertinimas nebuvo nagrinejjamas. Galima pastebẻti, kad paauglių subjektyvų sveikatos įvertinimą gali veikti ịvairūs veiksniai - pradedant nuo objektyvių sveikatos rodiklių (ligos, traumos) iki psichologinių ar socialinių veiksnių, tokių kaip šeima, bendraamžiai, mokyklos aplinka. Atsižvelgiant ị tai, ateityje atliekant panašaus pobūdžio tyrimus vertètų pagalvoti apie papildomų veiksnių analizę, pavyzdžiui, patiriamus skausmus, psichosomatinius simptomus, miego kokybę, socialinę paramą, užimtumą mokymusi ir kt.

Apibendrinant galima teigti, kad yra svarbu išlaikyti holistinị požiūrị i asmens sveikatą ir gerovę. Kadangi paauglysteje sąlyginai nedaug moksleivių serga somatinèmis ligomis, todèl psichikos sveikatai turètų būti skirtas ypatingas dėmesys. Siekiant išvengti neigiamų pasekmių ateityje, svarbu dar mokykliniame amžiuje identifikuoti sveikatos ir gerovės rodiklius bei skirti jiems pakankamą dėmesį, o esant reikalui - juos koreguoti.

\section{Išvados}

1. Daugelis Lietuvos moksleiviu yra patenkinti savo gyvenimu (87 proc.), savo sveikatą vertina kaip gerą arba puikią (87 proc.), dauguma moksleivių pasižymi aukštesniu nei vidutiniu psichologinès gerovès lygiu (69 proc.).

2. Prastesnis pasitenkinimas gyvenimu būdingas mergaitėms, vyresniems moksleiviams ir jauniems žmonėms iš žemesnès socialinès-ekonominès padèties šeimų.

3. Pasitenkinimas gyvenimu stipriai teigiamai susijęs su moksleiviu psichologine gerove ir subjektyviu sveikatos ivvertinimu. 


\section{Literatūra}

1. Huebner E, Suldo SM, Smith LC, McKnight CG. Life satisfaction in children and youth: empirical foundations and implications for school psychologists. Psychology in the Schools 2004;41(1):81-93.

https://doi.org/10.1002/pits.10140

2. Inchley J Currie D, Young T. et al. Growing up unequal: gender and socioeconomic differences in young people's health and well-being. Health Behaviour in School-aged Children (HBSC) study: international report from the 2013/2014 survey. Copenhagen, WHO Regional Office for Europe, 2016 (Health Policy for Children and Adolescents, No. 7).

3. Alonso Y. The biopsychosocial model in medical research: the evolution of the health concept over the last two decades. Patient education and counseling 2004;53(2):239-244. https://doi.org/10.1016/S0738-3991(03)00146-0

4. Cavallo F, Dalmasso P, Ottova-Jordan V. et al. Trends in selfrated health in European and North-American adolescents from 2002 to 2010 in 32 countries. The European Journal of Public Health 2015;25(suppl 2):13-15.

https://doi.org/10.1093/eurpub/ckv011

5. Idler EL, Benyamini Y. Self-rated health and mortality: a review of 27 community studies. J Health Soc Behav 1997; 38(1):21-37. https://doi.org/10.2307/2955359

6. Bamia C, Orfanos P, Juerges H. Self-rated health and all cause and cause specific mortality of older adults: individual data metaanalysis of prospective cohor studies in the CHANCES Consortium. Maturitas 2017;103:37-44. https://doi.org/10.1016/j.maturitas.2017.06.023

7. World Health Organization. Wellbeing measures in primary health care/the depcare project. WHO Regional Office for Europe: Copenhagen, 1998.

8. Kaplan GA, Camacho T. Perceived health and mortality: a nine-year follow-up of the human population laboratory cohort. American Journal of Epidemiology 1983;117(3):292-304. https://doi.org/10.1093/oxfordjournals.aje.a113541

9. Cantril H. The pattern of human concern. Rutgers University Press 1965.

10. Zaborskis A, Makari J, Žemaitienè N. Lietuvos moksleivių psichologinè būsena. Biomedicina, 2002; 2(2):107-112.

11. Cheung F, Lucas RE. When does money matter most? examining the association between income and life satisfaction over the life course. Psychology and Aging 2015;30(1):120.

https://doi.org/10.1037/a0038682
12. Denegri Coria M, González Rivera N, Elgueta Sepúlveda H, García. et al. Life satisfaction in Chilean university students: an examination of the relation between gender and socioeconomic level. CES Psychología 2018;11(1):40-55.

https://doi.org/10.21615/cesp.11.1.4

13. Greenstein TN. Gender, Marital Status and Life Satisfaction, 2016. https://doi.org/10.31235/osf.io/ah5ty

14. Ojha R, Kumar V. A study on life satisfaction and emotional wellbeing among University students. Indian Journal of Positive Psychology 2017;8(2):112-116.

15. Whitley E, Popham F; Benzeval M. Comparison of the RoweKahn model of successful aging with self-rated health and life satisfaction: The West of Scotland twenty-07 prospective cohort study. The Gerontologist 2016;56(6):1082-1092.

https://doi.org/10.1093/geront/gnv054

16. Kavaliauskienė A, Šidlauskas A, Zaborskis A. Association between global life satisfaction and self-rated oral health conditions among adolescents in Lithuania. International Journal of Environmental Research and Public Health 2017;14(11):1338. https://doi.org/10.3390/ijerph14111338

\section{LIFE SATISFACTION AMONG LITHUANIAN SCHOOLCHILDREN: RESULTS OF THE HBSC STUDY \\ J.Lukoševičiūtė, K.Šmigelskas}

Keywords: life satisfaction, subjective self-rated health, wellbeing, schoolchildren, HBSC study.

Summary

Good physical and mental health and favourable social environment enables young people smoothly tackle adolescent challenges and decreases the risk of serious health issues in the future. This study aimed to establish the significance of self-rated health and psychological wellbeing on life satisfaction. The data were collected in 2018 in Lithuania using the HBSC international protocol. The sample comprised 4191 schoolchildren, grades 5, 7, and 9 (boys $50.9 \%$, girls $49.1 \%$, mean age $13.8 \pm 1.7$ years). Majority of Lithuanian schoolchildren (87\%) have high life satisfaction. Lower life satisfaction was observed among girls, older schoolchildren and the ones from families with the lower socioeconomic status. The most significant factors for life satisfaction were psychological wellbeing and self-rated health.

Correspondence to: juste.lukoseviciute@1smuni.lt

Gauta 2019-07-12 